\title{
Oxidative stability and total lipids on thigh and breast meat of broilers fed diets with two fat sources and supplemented with conjugated linoleic acid
}

\author{
S.F. Zanini ${ }^{\mathrm{a}, *}$, G.L. Colnago ${ }^{\mathrm{b}}$, M.R. Bastos ${ }^{\mathrm{a}}$, B.M.S. Pessotti ${ }^{\mathrm{a}}$, \\ F.P. Casagrande ${ }^{\mathrm{a}}$, V.R. Lima ${ }^{\mathrm{a}}$ \\ a Department of Veterinary Sciences, PO Box 16, CEP 29500-000 Espirito Santo Federal University, Alegre (ES), Brazil \\ ${ }^{\mathrm{b}}$ Department of Animal Sciences, Fluminense Federal University, Brazil
}

Received 14 February 2005; received in revised form 3 May 2005

\begin{abstract}
Two hundred broiler chickens of 21 days of age were distributed in a completely randomized factorial arrangement $2 \times 5$ (two oil sources, i.e. soybean or canola oil and five levels of CLA supplementation, i.e. $0.0 \%, 0.25 \%, 0.50 \%, 0.75 \%$ and $1.00 \%$ ). The purpose of this study was to evaluate the dietary supplementation of broiler diets with CLA and oil sources on the lipid content and on the oxidative stability of chicken meat submitted to refrigeration or freezing storage temperatures. The use of canola oil and increasing CLA levels resulted in a linear reduction $(P<0.05)$ on the total lipids in breast meat. These results can explain a linear reduction $(P<0.05)$ observed in the malonaldehyde content of refrigerated and frozen meat of birds receiving canola oil. Birds receiving soybean oil and supplemented with CLA showed an abrupt reduction of total lipids on breast meat from $0.89 \mathrm{~g} / 100 \mathrm{~g}$ at $0 \%$ CLA to $0.36 \mathrm{~g} / 100 \mathrm{~g}$ at $0.5 \%$ CLA followed by a small increase at higher levels of CLA $(P<0.05)$. These observations may help to explain the reduction $(P<0.05)$ of oxidation in breast meat during frozen storage at 50 and 100 days as well as during cold storage at $5{ }^{\circ} \mathrm{C}$.

(C) 2005 Swiss Society of Food Science and Technology. Published by Elsevier Ltd. All rights reserved.
\end{abstract}

Keywords: Broilers; Malonaldehyde; Meat; Lipids; Conjugated linoleic acid

\section{Introduction}

Improving food quality and nutritional value is an important tool used by modern nutritionist to help, not only feed an ever-increasing human population, but also to enhance health and longevity. The metabolic diseases and disturbs associated with age and longevity of the human population brought about an increased interest for the so-called functional foods, i.e. foods that besides supplying nutrients to support the normal functioning

\footnotetext{
${ }^{*}$ Corresponding author. Tel.: + 552835528916 ; fax: +552835522622 .

E-mail addresses: surama@cca.ufes.br (S.F. Zanini), colnago@tropical.com.br (G.L. Colnago).
}

of the human organism have also nonnutritious compounds that may help prevent diseases. There are a vast number of compounds present in food that have improving health status characteristics, among these are the polyunsaturated fatty acids.

Conjugated linoleic acid (CLA) is the denomination of geometric isomers of linoleic acid (C18:2 $\omega 6)$. The conjugation of the double bonds are generally in the positions 9 and 11, or 10 and 12, and may be cis or trans (Ip, Singh, Thompson, \& Scimeca, 1994; Parodi, 1977). CLA is known as a functional element since it is among the compounds having anticarcinogenic properties (Cesano, Visonneau, Scimeca, Kritchevky, \& Santoli, 1998; Ip \& Scimeca, 1997; Wong et al., 1997). Besides the anticarcinogenic properties it also has hypocholes- 
terolemic effects (Kelly \& Bauman, 1996; Lee, Kritchevsky, \& Pariza, 1994; ), acts as an antiatherosclerotic agent (Lee et al., 1994), and stimulates an immune system (Cook, Miller, Park, \& Pariza, 1993). CLA daily intake of the occidental population is estimated at $1 \mathrm{~g} /$ day/person which is below the recommended level of $3.5 \mathrm{~g}$ therefore, dietary supplementation should be used (Ip et al., 1994).

Dietary supplementation with CLA may change the composition of lipids produced by the liver (Belury \& Kempa-Steczko, 1997) as well as reduce the total lipid concentration in rats (West et al., 1998). These alterations on the lipid profile by CLA supplementation may also result in changes of the oxidative stability of tissues. Joo, Lee, Ha, and Park (2002) supplemented finishing swine diets with CLA and observed that thiobarbituric acid-reactive substances (TBARS) values in the meat during cold storage at $4{ }^{\circ} \mathrm{C}$ for 7 days were higher for animals fed the control diet. Similar results were reported by Corino, Mourot, Magni, Pastorelli, and Rosi (2002) in the meat of rabbits fed diets with $0.5 \%$ CLA. No information was found in the literature about the oxidative stability of broiler meat fed diets supplemented with different oil sources and enriched with CLA. It is believed that this association may change carcass lipid content as well as oxidative stability.

The purpose of this study was to evaluate the dietary supplementation of broiler diets with CLA and oil sources on the lipid content, and the oxidative stability of chicken meat submitted to refrigeration, or freezing storage temperatures.

\section{Material and methods}

Two hundred broiler chickens of 21 days of age were distributed in a completely randomized factorial arrangement $2 \times 5$ (two oil sources, i.e. soybean or canola oil and five levels of CLA supplementation, i.e. 0.0, 0.25, $0.50,0.75$ and $1.00 \%$ ). Oils used were supplied by Bünge Alimentos and CLA (LUTA ${ }^{\circledR}$-CLA 60), by BASF. The source of CLA contained $\sim 60 \%$ conjugated isomers, as a 50:50 mixture of 18:2 cis-9, trans-11 and 18:2 trans-10, cis-12. The control diets had $4 \%$ of soybean or canola oil. CLA supplementation levels were obtained by isometrically replacing soybean or canola oil in the control diets. The ration of fatty acids $\omega 6: \omega 3$ in the soybean and canola oils were $12: 1$ and $3.5: 1$, respectively.

From 1 to 21 days of age, chicks were raised on a corn-soy diet with $21 \%$ protein and $2950 \mathrm{Kcal}$ of metabolizable energy per kilogram of diet. From 22 to 45 days of age the experimental diets were a corn-soy diets (Table 1). The main fatty acids found in the oils are given in Table 2. At 45 days of age, birds were killed by a cut in the jugular vein. Samples of breast and thigh
Table 1

Composition of the basal diet

\begin{tabular}{lr}
\hline Ingredients & $(\mathrm{g} / 100 \mathrm{~g})$ \\
\hline Ground yellow maize & 60.86 \\
Soybean meal & 31.50 \\
Canola or soybean oil & 4.00 \\
Dicalcium phosphate & 1.50 \\
Limestone & 1.20 \\
Sodium chloride & 0.40 \\
Vitamin supplement ${ }^{\mathrm{a}}$ & 0.20 \\
Mineral supplement $^{\mathrm{b}}$ & 0.07 \\
Salinomycin, & 0.05 \\
Dl- methionine & 0.18 \\
Zinc Bacitracin, & 0.03 \\
Antioxidant (BHT) & 0.01 \\
Calculated composition & \\
Crude protein, & 19.00 \\
Metabolizable energy, kcal/kg & 3150.00 \\
Analysed composition & \\
Dry matter & 89.56 \\
Crude protein, & 18.70 \\
Total fat, & 6.70
\end{tabular}

${ }^{\text {a }}$ Supply per kilogram of product the following vitamins and mineral: Vit. A, 15000000 UI, Vit. $D_{3}, 1500000$ UI, Vit. E, 15000 UI, Vit. $K_{3}$, $3 \mathrm{~g}$, Vit. $\mathrm{B}_{1}, 2 \mathrm{~g}$, Vit. $\mathrm{B}_{2} 4 \mathrm{~g}$, Vit $\mathrm{B}_{6}, 3 \mathrm{~g}$, Vit $\mathrm{B}_{12}, 0.015 \mathrm{~g}$, niacin, $2 \mathrm{~g}$, pantothenic acid, $10 \mathrm{~g}$, folic acid, $1 \mathrm{~g}$, Choline, $250 \mathrm{~g}$, selenium, $100 \mathrm{mg}$ e and q.s.p., $1000 \mathrm{~g}$.

${ }^{\mathrm{b}}$ Supply per kilogram of product the following minerals: Fe, $80 \mathrm{~g}$, $\mathrm{Cu}, 10 \mathrm{~g}, \mathrm{Co}, 2 \mathrm{~g}, \mathrm{Zn}, 50 \mathrm{~g}, \mathrm{Mn}, 60 \mathrm{~g}, \mathrm{I}, 1 \mathrm{~g}$ and q.s.p., $500 \mathrm{~g}$.

Table 2

Profile of fatty acids ( $\%$ of total fatty acids) found in the oils added to the experimental diets

\begin{tabular}{|c|c|c|}
\hline \multirow[t]{2}{*}{ Fatty acids $(\%)$} & \multicolumn{2}{|l|}{ Oils } \\
\hline & Soybean & Canola \\
\hline $\mathrm{C} 14: 0$ & ND & ND \\
\hline C15:0 & ND & ND \\
\hline $\mathrm{C} 16: 0$ & 11.6 & 5.1 \\
\hline $\mathrm{C} 16: 1 \omega 7$ & 0.1 & 0.2 \\
\hline $\mathrm{C} 17: 0$ & ND & ND \\
\hline C18:0 & 3.8 & 2.6 \\
\hline 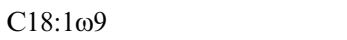 & 24.2 & 64.1 \\
\hline $\mathrm{C} 18: 2 \omega 6$ & 54.8 & 19.4 \\
\hline $\mathrm{C} 18: 3 \omega 3 \alpha$ & 4.5 & 6.1 \\
\hline $\mathrm{C} 18: 3 \omega 6 \gamma$ & 0.6 & 1.2 \\
\hline C20:0 & 0.2 & 0.2 \\
\hline $\mathrm{C} 20: 1 \omega 11$ & 0.2 & 1.1 \\
\hline $\mathrm{C} 20: 4 \omega 6$ & ND & ND \\
\hline $\mathrm{C} 20: 5 \omega 3$ (EPA) & ND & ND \\
\hline $\mathrm{C} 22: 6 \omega 3$ (DHA) & ND & ND \\
\hline Saturated & 15.6 & 7.9 \\
\hline Monounsaturated & 24.5 & 65.4 \\
\hline Polyunsaturated & 59.9 & 26.7 \\
\hline Omega-6 $(\omega 6)$ & 55.4 & 20.6 \\
\hline Omega-3 ( $\omega 3)$ & 4.5 & 6.1 \\
\hline Ratio of $\omega 6: \omega 3$ & 12.31 & 3.37 \\
\hline Unsaturated:saturated (I:S) & 5.41 & 11.66 \\
\hline
\end{tabular}

$\mathrm{ND}=$ not detected 
meat were collected. Of these samples, half of breast and thigh meat was kept under refrigeration at $5{ }^{\circ} \mathrm{C}$, and the other half was kept under freezing conditions at $-20^{\circ} \mathrm{C}$. Oxidative stability was measured on meats kept under refrigeration after the third day of storage, and on the frozen meat on days $25,50,75$ and 100 of storage. Oxidative stability was measured using the procedure described by Tarladgis, Watts, Younathan, and Dugan (1960) for the TBARS values. The lipids contained in the thigh and breast meat were extracted using the technique of Folch, Lees, and Sloane-Stanley (1957).

The experimental data was subjected to an analysis of variance using the System for Statistical and Genetic Analyses, developed by UFV (1997). Significant differences among means were determined by SNK test at $P<0.05$ throughout this study. Regression analysis was used to report the effects of CLA levels. When there was an interaction $(P<0.05)$, the effect of the CLA level inside each oil source was determined according to Banzatto and Kronka (1992).

\section{Results and discussion}

Under storage conditions fats and the lipid content of foods may undergo oxidation. The rate of oxidation depends upon the fat level, profile of fatty acids, and the storage conditions. The malonaldehyde is formed primarily by the oxidation of unsaturated fatty acids, with the reaction being more intense as the level of unsaturation of the fat increases (Janero, 1990).

The results of oxidative stability of breast and thigh meat stored under freezing conditions show that oxidation of both, the breast and thigh meat, occurred slowly and followed a linear increase in oxidation with length of storage (Table 3), which corroborates previous

Table 3

TBARS values (mg of malonaldehyde/ $\mathrm{kg}$ meat) of frozen breast and thigh meat of broilers fed diets with canola or soybean oil and CLA under different storage time

\begin{tabular}{|c|c|c|c|c|}
\hline \multirow[t]{3}{*}{ CLA $(g / 100 \mathrm{~g})$} & \multicolumn{4}{|c|}{25 days of storage time } \\
\hline & \multicolumn{2}{|l|}{ Thigh meat } & \multicolumn{2}{|l|}{ Breast meat } \\
\hline & Soybean oil ${ }^{2}$ & Canola oil ${ }^{2}$ & Soybean oil ${ }^{1}$ & Canola oil \\
\hline 0.00 & $0.167^{\mathrm{a}}$ & $0.179^{\mathrm{a}}$ & $0.095^{\mathrm{a}}$ & $0.082^{\mathrm{a}}$ \\
\hline 0.25 & $0.106^{\mathrm{a}}$ & $0.094^{\mathrm{a}}$ & $0.056^{\mathrm{a}}$ & $0.043^{\mathrm{a}}$ \\
\hline 0.50 & $0.058^{\mathrm{b}}$ & $0.129^{\mathrm{a}}$ & $0.051^{\mathrm{b}}$ & $0.098^{\mathrm{a}}$ \\
\hline 0.75 & $0.070^{\mathrm{a}}$ & $0.082^{\mathrm{a}}$ & $0.050^{\mathrm{a}}$ & $0.048^{\mathrm{a}}$ \\
\hline 1.00 & $0.084^{\mathrm{b}}$ & $0.121^{\mathrm{a}}$ & $0.039^{\mathrm{b}}$ & $0.078^{\mathrm{a}}$ \\
\hline SEM & \multicolumn{2}{|c|}{0.0118} & \multicolumn{2}{|c|}{0.0088} \\
\hline Probabilities & \multirow{2}{*}{\multicolumn{2}{|c|}{0.00000}} & \multirow{2}{*}{\multicolumn{2}{|c|}{0.00017}} \\
\hline CLA & & & & \\
\hline
\end{tabular}

Table 3 (continued)

TBARS values (mg de MDA $/ \mathrm{kg}$ meat)

CLA $(\mathrm{g} / 100 \mathrm{~g}) 25$ days of storage time

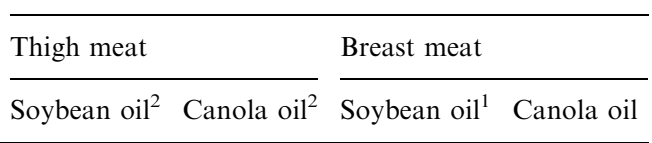

\begin{tabular}{lll}
\hline Oil & 0.00242 & 0.05181 \\
CLA $\times$ oil & 0.01356 & 0.00137
\end{tabular}

CLA (g/100 g) 50 days of storage time

\begin{tabular}{|c|c|c|c|c|}
\hline & \multicolumn{2}{|l|}{ Thigh meat } & \multicolumn{2}{|l|}{ Breast meat } \\
\hline & Soybean oil ${ }^{2}$ & Canola oil $1^{2}$ & Soybean oil ${ }^{2}$ & Canola oil \\
\hline 0.00 & $0.187^{\mathrm{a}}$ & $0.187^{\mathrm{a}}$ & $0.165^{\mathrm{a}}$ & $0.111^{\mathrm{b}}$ \\
\hline 0.25 & $0.125^{\mathrm{a}}$ & $0.112^{\mathrm{a}}$ & $0.112^{\mathrm{a}}$ & $0.109^{\mathrm{a}}$ \\
\hline 0.50 & $0.156^{\mathrm{a}}$ & $0.148^{\mathrm{a}}$ & $0.104^{\mathrm{a}}$ & $0.129^{\mathrm{a}}$ \\
\hline 0.75 & $0.207^{\mathrm{a}}$ & $0.142^{\mathrm{b}}$ & $0.180^{\mathrm{b}}$ & $0.106^{\mathrm{b}}$ \\
\hline 1.00 & $0.216^{\mathrm{a}}$ & $0.140^{\mathrm{b}}$ & $0.165^{\mathrm{b}}$ & $0.115^{\mathrm{b}}$ \\
\hline SEM & \multirow{2}{*}{\multicolumn{2}{|c|}{0.0102}} & \multicolumn{2}{|c|}{0.0127} \\
\hline Probabilities & & & \multirow{2}{*}{\multicolumn{2}{|c|}{0.04175}} \\
\hline CLA & \multicolumn{2}{|c|}{0.00000} & & \\
\hline Oil & \multicolumn{2}{|c|}{0.00002} & \multicolumn{2}{|c|}{0.00036} \\
\hline CLA $\times$ oil & \multicolumn{2}{|c|}{0.00073} & \multicolumn{2}{|c|}{0.00189} \\
\hline
\end{tabular}

CLA $(\mathrm{g} / 100 \mathrm{~g}) 75$ days of storage time

\begin{tabular}{|c|c|c|c|c|}
\hline & \multicolumn{2}{|l|}{ Thigh meat } & \multicolumn{2}{|l|}{ Breast meat } \\
\hline & Soybean oil & Canola oil & Soybean oil & Canola oil ${ }^{1}$ \\
\hline 0.00 & 0.267 & 0.238 & $0.196^{\mathrm{a}}$ & $0.193^{\mathrm{a}}$ \\
\hline 0.25 & 0.231 & 0.227 & $0.161^{\mathrm{a}}$ & $0.185^{\mathrm{a}}$ \\
\hline 0.50 & 0.224 & 0.252 & $0.173^{\mathrm{a}}$ & $0.143^{\mathrm{a}}$ \\
\hline 0.75 & 0.218 & 0.203 & $0.176^{\mathrm{a}}$ & $0.115^{\mathrm{b}}$ \\
\hline 1.00 & 0.230 & 0.235 & $0.160^{\mathrm{a}}$ & $0.106^{\mathrm{b}}$ \\
\hline SEM & \multirow{2}{*}{\multicolumn{2}{|c|}{0.0173}} & \multicolumn{2}{|c|}{0.0110} \\
\hline Probabilities & & & \multirow{2}{*}{\multicolumn{2}{|c|}{0.00003}} \\
\hline CLA & \multicolumn{2}{|c|}{$\mathrm{ns}$} & & \\
\hline Oil & \multicolumn{2}{|c|}{ ns } & \multicolumn{2}{|c|}{0.00114} \\
\hline CLA $\times$ oil & \multicolumn{2}{|c|}{ ns } & \multicolumn{2}{|c|}{0.00177} \\
\hline
\end{tabular}

CLA (g/100 g) 100 days of storage time

\begin{tabular}{|c|c|c|c|c|}
\hline & Thigh meat & & Breast meat & \\
\hline & Soybean oil & Canola oil & Soybean oil ${ }^{2}$ & Canola oil \\
\hline 0.00 & 0.325 & 0.268 & $0.206^{\mathrm{a}}$ & $0.232^{\mathrm{a}}$ \\
\hline 0.25 & 0.305 & 0.269 & $0.176^{\mathrm{a}}$ & $0.219^{\mathrm{a}}$ \\
\hline 0.50 & 0.296 & 0.349 & $0.170^{\mathrm{b}}$ & $0.221^{\mathrm{a}}$ \\
\hline 0.75 & 0.368 & 0.355 & $0.215^{\mathrm{a}}$ & $0.215^{\mathrm{a}}$ \\
\hline 1.00 & 0.358 & 0.327 & $0.235^{\mathrm{a}}$ & $0.198^{\mathrm{a}}$ \\
\hline SEM & 0.0 & & 0.0 & \\
\hline Probabilities & & & & \\
\hline CLA & 0.02 & 076 & $\mathrm{n}$ & \\
\hline Oil & $\mathrm{n}$ & & $\mathrm{n}$ & \\
\hline CLA $\times$ oil & $\mathrm{n}$ & & 0.03 & \\
\hline
\end{tabular}

\footnotetext{
${ }^{\mathrm{a}, \mathrm{b}}$ Averages values within the same row with no common superscript differ significantly by the SNK test $(P<0.05)$.

${ }^{1}$ Linear effect $(P<0.05)$

${ }^{2}$ Quadratic effect $(P<0.05)$.
} 


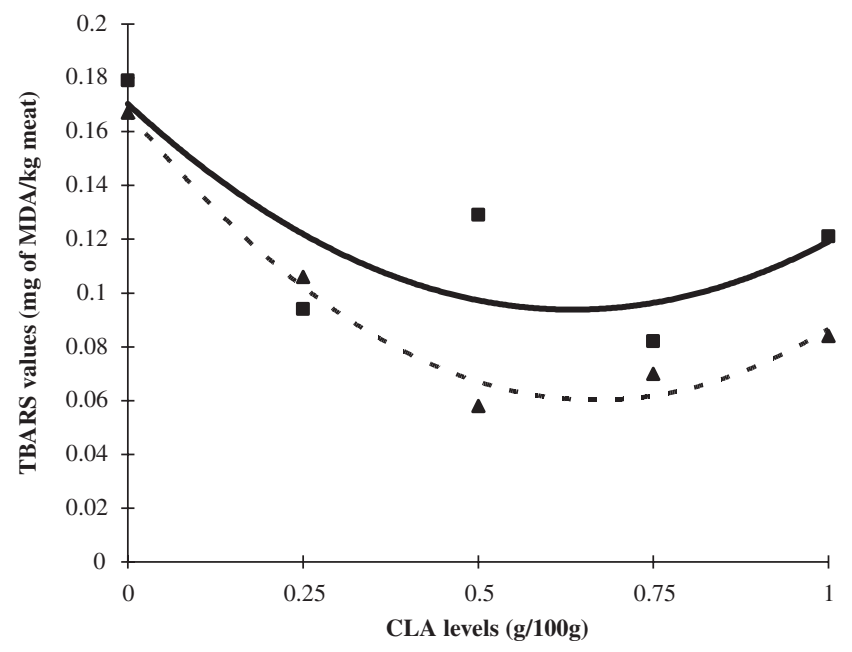

Fig. 1. TBARS values ( $\mathrm{mg}$ of MDA $/ \mathrm{kg}$ meat) of frozen thigh meat of broilers fed diets with soybean oil $(\boldsymbol{\Lambda}-\hat{Y}=0.167366-0.321182 x+$ $\left.0.240686 x^{2}, R^{2}=0.98\right)$ or canola oil $(\boldsymbol{\square}-\hat{Y}=0.170486-0.24131 x+$ $0.190766 x^{2}, R^{2}=0.63$ ) and CLA levels, stored for 25 days. Each value is expressed as mean \pm standard deviation $(n=5)$.

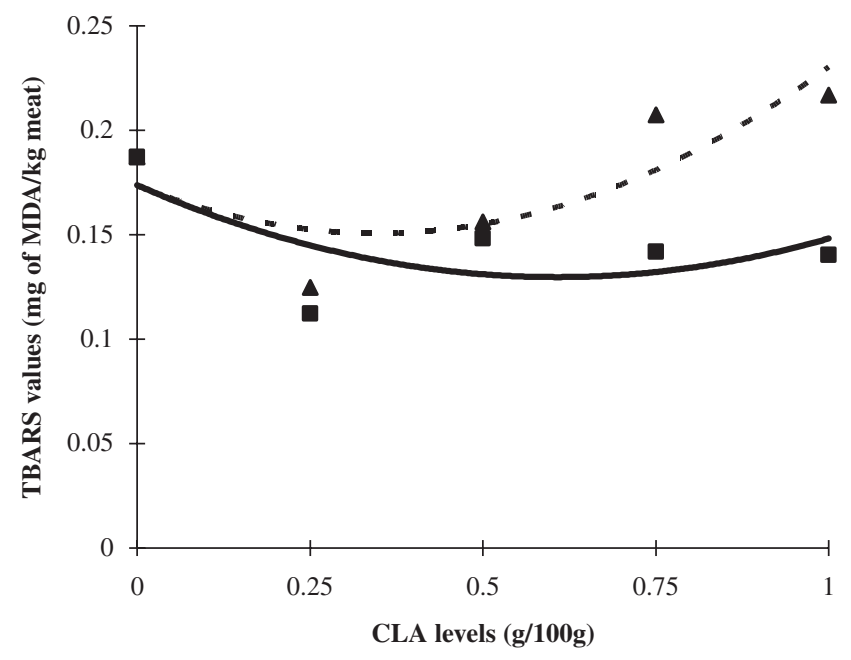

Fig. 2. TBARS values (mg of MDA $/ \mathrm{kg}$ meat) of frozen thigh meat of broilers fed diets with soybean oil $(\boldsymbol{\Delta}-\hat{Y}=0.173472-0.130416 x+$ $\left.0.187200 x^{2}, \quad R^{2}=0.6808\right)$ or canola oil $(\boldsymbol{\square}-\hat{Y}=0.173739-$ $\left.0.145035 x+0.119451 x^{2}, R^{2}=0.4124\right)$ and CLA levels, stored for 50 days. Each value is expressed as mean \pm standard deviation $(n=5)$.

studies by Gava (1984), that reported that in frozen food the enzymatic reactions occur at a slow but continuing rate. In the thigh meat, during the first 50 days of storage, a significant interaction was observed between the source of oil and level of CLA on TBARS values. These results are better explained by a quadratic function (Figs. 1 and 2, $P<0.05$ ) that explains this interaction. At day 25 of storage, significant reduction on TBARS values on thigh meat of broilers fed soybean oil $\left(\hat{Y}=0.167366-0.321182 x+0.240686 x^{2}\right.$,

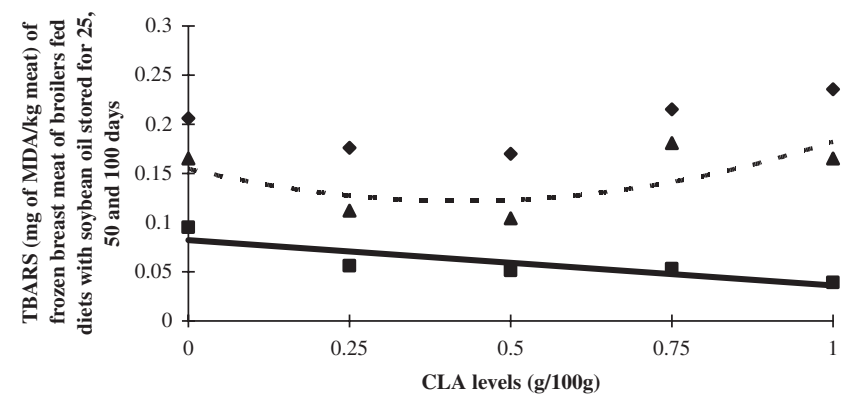

Fig. 3. TBARS values ( $\mathrm{mg}$ of MDA $/ \mathrm{kg}$ meat) of frozen breast meat of broilers fed diets with soybean oil and CLA levels, stored for 25 days $\left(\boldsymbol{\square}-\hat{Y}=0.0818-0.0472 x, R^{2}=0.75\right), 50$ days $(\boldsymbol{\Delta}-\hat{Y}=0.154707-$ $\left.0.15439 x+0.181851 x^{2}, R^{2}=0.47\right)$ and 100 days $(-\hat{Y}=0.202577-$ $\left.0.133625 x+0.172937 x^{2}, R^{2}=0.87\right)$. Each value is expressed as mean \pm standard deviation $(n=5)$.

$\left.R^{2}=0.98\right)$ and canola oil $(\hat{Y}=0.170486-0.24131 x+$ $0.190766 x^{2}, R^{2}=0.63$ ) was observed. This reduction plateau between $0.50 \%$ and $0.75 \%$ of CLA level. At 25 days of storage, supplementation with $0.50 \%$ of CLA in association with soybean oil resulted in lower TBARS values for both breast and thigh meat when compared to that of canola oil supplemented birds $(P<0.05)$. However, on days 75 and 100 of storage, this interaction was not observed $(P>0.05)$.

A significant interaction between the source of oil and level of CLA was also observed on TBARS values of breast meat during frozen storage (Table 3). The breast meat of birds fed the soybean oil showed linear reduction $(P<0.05)$ of TBARS values with increasing CLA levels at 25 days of storage $(\hat{Y}=0.0818-0.0472 x$, $R^{2}=0.75$, Fig. 3). However, as storage time increased, the interactive effect of oil source and levels of CLA on TBARS values of breast meat was better explained by a quadratic function. On days $50(\hat{Y}=0.154707-$ $0.15439 x+0.181851 x^{2}, R^{2}=0.47$, Fig. 3) and 100 $\left(\hat{Y}=0.202577-0.133625 x+0.172937 x^{2}, \quad R^{2}=0,87\right.$, Fig. 3) of storage, a reduction of oxidation of the breast meat was observed due to birds fed a diet containing soybean oil and supplemented with up to $0.50 \%$ of CLA. The same was observed in the thigh meat of birds receiving soybean oil and CLA at day 50 of storage $\left(\hat{Y}=0.2178-0.056 x+0.0117 x^{2}, R^{2}=0.68\right)$. At this storage time, levels of $0.75 \%$ of CLA in association with canola oil resulted in lower oxidation on both breast and thigh meat when compared to soybean oil $(P<0.05)$. At 75 days of storage, again $0.75 \%$ of CLA in association with canola oil resulted in lower breast meat oxidation. Also, there was a linear reduction on TBARS values with increasing levels of CLA on breast meat of canola oil diet fed birds stored for 75 days $\left(\hat{Y}=0.197808-0.097968 x, R^{2}=0.94\right)$. These overall results showed a synergistic effect between CLA and oil source to improve oxidative stability on breast and thigh meat during frozen storage. According to Shantha, 
Table 4

TBARS values ( $\mathrm{mg}$ of malonaldehyde $/ \mathrm{kg}$ meat) of refrigerated breast and thigh meat of broilers fed diets with canola or soybean oil and CLA

TBARS values (mg de MDA $/ \mathrm{kg}$ meat)

\begin{tabular}{|c|c|c|c|}
\hline \multirow[t]{2}{*}{ CLA (g/100g) } & \multicolumn{3}{|l|}{ Thigh meat } \\
\hline & \multicolumn{2}{|l|}{ Soybean oil } & Canola oil $^{2}$ \\
\hline 0.00 & \multicolumn{2}{|l|}{$0.158^{\mathrm{b}}$} & $0.214^{\mathrm{a}}$ \\
\hline 0.25 & \multicolumn{2}{|l|}{$0.152^{\mathrm{a}}$} & $0.159^{\mathrm{a}}$ \\
\hline 0.50 & \multicolumn{2}{|l|}{$0.119^{\mathrm{a}}$} & $0.122^{\mathrm{a}}$ \\
\hline 0.75 & \multicolumn{2}{|l|}{$0.176^{\mathrm{a}}$} & $0.152^{\mathrm{a}}$ \\
\hline 1.00 & \multicolumn{2}{|l|}{$0.156^{\mathrm{a}}$} & $0.124^{\mathrm{b}}$ \\
\hline SEM & & 0.0101 & \\
\hline \multicolumn{4}{|l|}{ Probabilities } \\
\hline \multicolumn{4}{|l|}{ CLA } \\
\hline \multirow{2}{*}{\multicolumn{4}{|c|}{$\begin{array}{l}\text { Oil } \\
\text { CLA } \times \text { oil }\end{array}$}} \\
\hline & & & \\
\hline \multirow[t]{2}{*}{ CLA (g/100g) } & \multicolumn{3}{|l|}{ Breast meat } \\
\hline & \multicolumn{2}{|l|}{ Soybean oil ${ }^{2}$} & Canola oil $^{1}$ \\
\hline 0.00 & \multicolumn{2}{|l|}{$0.149^{\mathrm{a}}$} & $0.140^{\mathrm{a}}$ \\
\hline 0.25 & \multicolumn{2}{|l|}{$0.066^{\mathrm{b}}$} & $0.150^{\mathrm{a}}$ \\
\hline 0.50 & \multicolumn{2}{|l|}{$0.121^{\mathrm{a}}$} & $0.108^{\mathrm{a}}$ \\
\hline 0.75 & \multicolumn{2}{|l|}{$0.091^{\mathrm{a}}$} & $0.112^{\mathrm{a}}$ \\
\hline 1.00 & \multicolumn{2}{|l|}{$0.106^{\mathrm{a}}$} & $0.095^{\mathrm{a}}$ \\
\hline \multicolumn{2}{|l|}{ SEM } & 0.0129 & \\
\hline \multicolumn{4}{|l|}{ Probabilities } \\
\hline \multicolumn{2}{|l|}{ CLA } & 0.01260 & \\
\hline \multicolumn{2}{|l|}{ Oil } & Ns & \\
\hline \multicolumn{2}{|l|}{ CLA $\times$ Oil } & 0.00219 & \\
\hline
\end{tabular}

${ }^{\mathrm{a}, \mathrm{b}}$ Averages values within the same row with no common superscript differ significantly by the SNK test $(P<0.05)$.

${ }^{1}$ Linear effect $(P<0.05)$.

${ }^{2}$ Quadratic effect $(P<0.05)$.

Crum, and Decker (1994) and Shantha, Ram, O'Leary, Hicks, and Decker (1995), the CLA is a stable fat, and its deposition on carcass fat could reduce the oxidative potential when compared to other fats higher in polyunsaturated fatty acids.

These results also showed that the TBARS index, in absolute values, was higher for thigh meat than in the breast meat of broilers, probably due to its higher lipid content what is in agreement with the results of Sirri, Minelli, Meluzzi, and Franchini (2003).

The results of oxidative stability of breast and thigh meat stored under refrigeration are shown in Table 4. A significant interaction between the source of oil and level of CLA in the diet on TBARS values of refrigerated meat was observed. On the breast meat, was observed a linear reduction on TBARS values with increasing levels of CLA in association with canola oil ( $\hat{Y}=0.147174-$ $\left.0.05164 x, R^{2}=0.77\right)$. On breast meat from birds fed soybean oil diets, variation on TBARS values was best explained by a quadratic function $(\hat{Y}=0.135407-$
Table 5

Lipid content of thigh and breast meat from broilers fed diets with canola or soybean oil and increasing levels of CLA

\begin{tabular}{|c|c|c|c|}
\hline \multirow[t]{2}{*}{ CLA (g/100g) } & \multicolumn{3}{|c|}{ Lipid content on thigh meat $(\mathrm{g} / 100 \mathrm{~g})$} \\
\hline & Soybean oil ${ }^{1}$ & Canola oil ${ }^{1}$ & $\bar{x}$ CLA \\
\hline 0.00 & $3.20^{\mathrm{b}}$ & $4.12^{\mathrm{a}}$ & 3.66 \\
\hline 0.25 & $3.64^{\mathrm{b}}$ & $5.17^{\mathrm{a}}$ & 4.40 \\
\hline 0.50 & $3.73^{\mathrm{a}}$ & $4.45^{\mathrm{a}}$ & 4.09 \\
\hline 0.75 & $3.80^{\mathrm{a}}$ & $3.69^{\mathrm{a}}$ & 3.74 \\
\hline 1.00 & $4.29^{\mathrm{a}}$ & $3.75^{\mathrm{a}}$ & 4.02 \\
\hline $\bar{x}$ oil source & $3.73^{\mathrm{b}}$ & $4.24^{\mathrm{a}}$ & \\
\hline \multirow{2}{*}{\multicolumn{4}{|c|}{$\begin{array}{l}\text { SEM } \\
\text { Probabilities }\end{array}$}} \\
\hline & & & \\
\hline CLA & & 0.24596 & \\
\hline Oil & & 0.02988 & \\
\hline CLA $\times$ oil & & 0.04433 & \\
\hline \multirow[t]{2}{*}{ CLA $(g / 100 \mathrm{~g})$} & \multicolumn{3}{|c|}{ Lipid content on breast meat $(\mathrm{g} / 100 \mathrm{~g})$} \\
\hline & Soybean oil ${ }^{2}$ & Canola oil $^{1}$ & $\bar{x}$ CLA \\
\hline 0.00 & $0.89^{\mathrm{b}}$ & $1.34^{\mathrm{a}}$ & 1.11 \\
\hline 0.25 & $0.66^{\mathrm{b}}$ & $1.33^{\mathrm{a}}$ & 0.99 \\
\hline 0.50 & $0.36^{\mathrm{b}}$ & $1.04^{\mathrm{a}}$ & 0.70 \\
\hline 0.75 & $0.46^{\mathrm{b}}$ & $1.09^{\mathrm{a}}$ & 0.78 \\
\hline 1.00 & $0.60^{\mathrm{a}}$ & $0.48^{\mathrm{a}}$ & 0.54 \\
\hline $\bar{x}$ oil source & $0.59^{\mathrm{b}}$ & $1.05^{\mathrm{a}}$ & \\
\hline SEM & & 0.113 & \\
\hline \multicolumn{4}{|l|}{ Probabilities } \\
\hline CLA & & 0.00015 & \\
\hline Oil & & 0.00000 & \\
\hline CLA $\times$ oil & & 0.00814 & \\
\hline
\end{tabular}

\footnotetext{
${ }^{\mathrm{a}, \mathrm{b}}$ Averages values within the same row with no common superscript differ significantly by the SNK test $(P<0.05)$.

${ }^{1}$ Linear effect $(P<0.05)$.

${ }^{2}$ Quadratic effect $(P<0.05)$.
}

$0.151443 x+0.126331 x^{2}$ ). The $0.25 \%$ level of CLA in association with soybean oil produced the lowest TBARS value on breast meat when compared with canola oil $(P<0.05)$.

On the thigh meat of broilers fed canola oil diets, variations on TBARS values followed a quadratic function $\left(P<0.05, \hat{Y}=0.208-0.213 x+0.139 x^{2}, R^{2}=\right.$ $0.81)$. Under refrigeration, supplementation of $1 \%$ of CLA in association with canola oil produced the lowest oxidation levels on the thigh meat when compared to that of birds fed soybean oil (Table 4).

A significant interaction between the source of oil and level of CLA was also observed on the total lipid content of thigh and breast meat (Table 5). The use of canola oil and increasing CLA levels resulted in a linear reduction $\left(P<0.05, \hat{Y}=1.44775-0.782667 x, R^{2}=0.78\right.$, Fig. 4) in the total lipids in breast meat and thigh meat $\left(P<0.05, \hat{Y}=4.682-0.885 x, R^{2}=0.33\right)$. These results can explain a linear reduction $(P<0.05)$ observed in the malonaldehyde content of frozen and refrigerated meat 


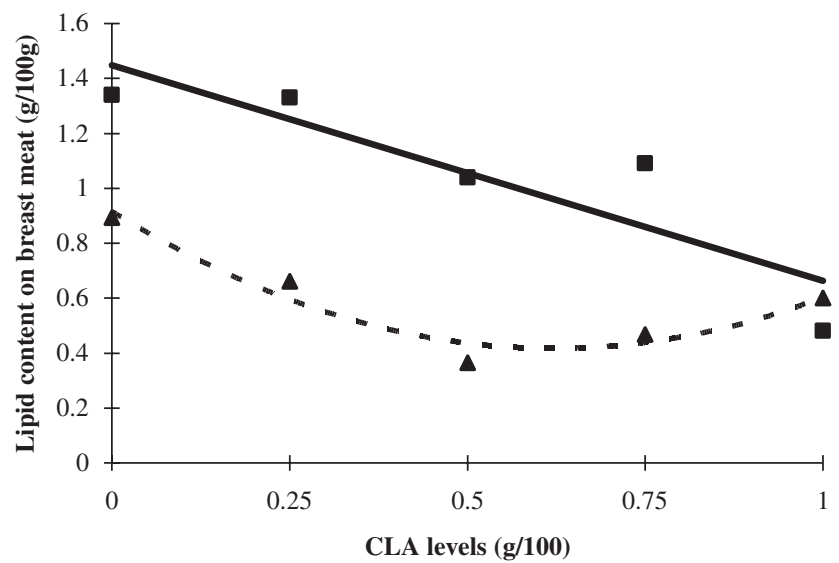

Fig. 4. Lipid content of frozen breast meat $(\mathrm{g} / 100 \mathrm{~g})$ from broilers fed diets with canola oil $\left(\mathbf{\square}-\hat{Y}=1.44775-0.782667 x, R^{2}=0.78\right)$ or soybean oil $\left(\boldsymbol{\Delta}-\hat{Y}=0.915264-1.60271 x+1.2897 x^{2}, R^{2}=0.93\right)$ and CLA supplementation levels. Each value is expressed as mean \pm standard deviation $(n=5)$.

of birds receiving canola oil (Tables 3 and 4, respectively). However, without CLA, total lipid content of breast meat $(1.34 \mathrm{~g} / 100 \mathrm{~g})$ of birds receiving canola oil was higher $(P<0.05)$ than that of birds on soybean oil $(0.89 \mathrm{~g} / 100 \mathrm{~g})$. This difference in lipid content did not influence the oxidative stability of the breast meat since there were no differences $(P>0.05)$ on oxidative stability between frozen breast meat at 25,75 and 100 days of storage or refrigerated at 3 days of storage, from chickens receiving canola or soybean oil, respectively (Tables 3 and 4). Birds receiving soybean oil diets and supplemented with CLA showed an abrupt reduction of total lipids on breast meat from $0.89 \mathrm{~g} / 100 \mathrm{~g}$ at $0 \%$ CLA to $0.36 \mathrm{~g} / 100 \mathrm{~g}$ at $0.5 \%$ CLA, followed by a small increase at higher levels of CLA $(P<0.05, \hat{Y}=$ $0.915264-1.60271 x+1.2897 x^{2}, \quad R^{2}=0.93, \quad$ Fig. 4). These results were explained by a quadratic response $(P<0.05)$. These observations may help to explain the reduction $(P<0.05)$ of oxidation on frozen (at 50 and 100 days of storage) and refrigerated breast meat from birds fed with soybean oil and CLA in the diet (Tables 3 and 4). For the thigh meat the results of total lipid content were similar to that of breast meat. Birds receiving canola oil diet without CLA had higher $(P<0.05)$ fat content $(4.12 \mathrm{~g} / 100 \mathrm{~g})$ as compared to broilers fed soybean oil diet $(3.20 \mathrm{~g} / 100 \mathrm{~g})$. The TBARS value of refrigerated thigh meat follows the fat content, where thigh meat of birds fed canola oil had TBARS value of 0.214 compared to 0.158 of birds fed soybean oil (Table 4). It is hypothesized that this effect observed on the thigh, but not on the breast meat, was due to the variation on the heme pigment of the two meats. According to Jones (1992), the concentration of heme pigments in breast and thigh meat of broilers is 0.5 and $1.7 \mathrm{mg} / \mathrm{g}$, respectively. The oxidation of the pigment may have catalysed the lipid oxidation, as reported by

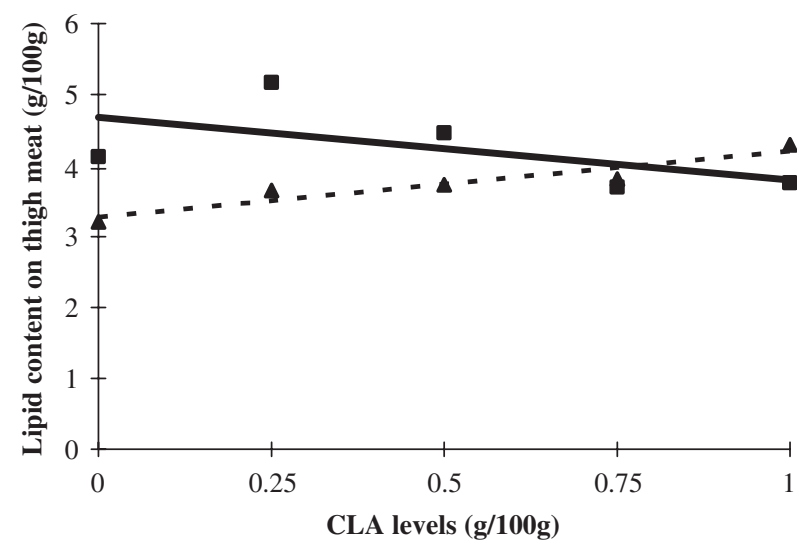

Fig. 5. Lipid content of frozen thigh meat $(\mathrm{g} / 100 \mathrm{~g})$ from broilers fed diets with canola oil $\left(\boldsymbol{\square}-\hat{Y}=4.682-0.885 x-R^{2}=0.33\right)$, or soybean oil $\left(\boldsymbol{\Delta}-\hat{Y}=3.269+0.931 x, R^{2}=0.90\right)$ and CLA supplementation levels. Each value is expressed as mean \pm standard deviation $(n=5)$.

Akamittath, Brekke, and Schanus (1990) and Monahan, Asghar, Gray, Buckley, and Morrissey (1994). On the other hand, feeding soybean oil with increasing levels of CLA produced a linear increase in total lipid content on thigh meat what may be responsible for the lack of difference between oil sources $(P<0.05, \hat{Y}=3.26975+$ $0.931 x, R^{2}=0,90$, Fig. 5, Table 5). These results agree with previous observations that have shown that when CLA is used in association with an oil source its effect may be modified. Brown, Evans, and McIntosh (2001) showed that a culture of pre-adipocites supplemented with CLA and sunflower oil (rich in $\omega 6$ fatty acids) had a higher triglyceride content than the culture receiving only CLA, showing that the antiadipogenic effect of the CLA in the pre-adipocites could be partially reversed. Therefore, results reported here show that, the association of CLA with other fats should be considered as well as the ratio of $\omega 6: \omega 3$ fatty acids, so that the effect of CLA may not be compromised. Aydin, Pariza, and Cook (2001) reported that the CLA effect is optimized when it is associated with a fat source rich in $\omega 3$ fatty acids or with diets that have a balanced ratio of $\omega 6: \omega 3$ fatty acids.

CLA has the potential to change the genic expression of lipogenic enzymes (Bauman, 2001). The present results demonstrated a synergistic effect between canola oil and CLA with a reduction on the total lipid content of thigh meat (linear effect, $P<0.05$ ) and on the breast meat (linear effect, $P<0.05$ ), and also an improvement in the oxidative stability of both meats during frozen (Table 3) and refrigerated storage (Table 4). On the other hand, an adipogenic effect was observed on the thigh meat when increasing levels of CLA were associated with soybean oil (Table 5). These results have shown that with soybean oil the CLA supplementation levels should not be above $0.25-0.50 \%$, so that 
the positive effect of CLA on the oxidative stability as well as on the meat composition is not eliminated as demonstrated by the TBARS index and total lipid content.

\section{Conclusions}

1. The synergistic effect between CLA and oil source improved oxidative stability of breast and thigh meat during frozen storage. This interaction effect was observed up to 50 days and 100 days for thigh and breast meat, respectively.

2. Under refrigeration, the lipid oxidation of the breast and the thigh meat was also minimized by the synergistic effect between CLA and the fat source. Under this storage condition the CLA was more efficient in reducing lipid oxidation when in association with canola oil as compared to soybean oil.

3. The CLA level for reducing TBARS index and total lipid content of meats was dependent on the fat source, the storage conditions, and the length of the storage period.

4. The improvement of the oxidative stability of breast and thigh meat of broiler chicks due to the synergistic effect between CLA and fat sources will allow the use of diets rich in polyunsaturated fatty acids without compromising the shelf-life of the meat.

\section{Acknowledgments}

The authors are grateful to the National Research Council (CNPq) for financial support and to the BASF S.A and Bunge Foods S.A. for technical support.

\section{References}

Akamittath, J. G., Brekke, C. J., \& Schanus, E. G. (1990). Lipid oxidation and color stability in restructured meat systems during frozen storage. Journal of Food Science, 55, 1513-1517.

Aydin, R., Pariza, M. W., \& Cook, M. E. (2001). Olive oil prevents the adverse effects of dietary conjugated linoleic acid on chick hatchability and egg quality. Journal of Nutrition, 131, 800-806.

Banzatto, D. A., \& Kronka, S. N. (1992). Experimentação agrícola. Jaboticabal: FUNEP.

Belury, M. A., \& Kempa-Steczko, A. (1997). Conjugated linoleic acid modulates hepatic lipid composition in mice. Lipids, 32, 199-204.

Brown, M., Evans, M., \& McIntosh, M. (2001). Linoleic acid partially restores the triglyceride content of conjugated linoleic acid-treated cultures of 3T3-L1 preadipocytes. Journal of Nutritional Biochemistry, 12, 381-387.

Cesano, A., Visonneau, S., Scimeca, J. A., Kritchevky, D., \& Santoli, D. (1998). Opposite effects of linoleic acid and conjugated linoleic acid on human prostatic cancer in SCID mice. Anticancer Research, 18, 1429-1434.

Cook, M. E. D., Miller, C. C., Park, Y., \& Pariza, M. W. (1993). Immune modulation by altered nutrient metabolism: nutritional control of immune-induced growth depression. Poultry Science, 72, 1301-1305.

Corino, C., Mourot, J., Magni, S., Pastorelli, G., \& Rosi, F. (2002). Influence of dietary conjugated linoleic acido on growth, meat quality, lipogenesis, plasma leptin and physiological variables of lipid metabolism in rabbits. Journal of Animal Science, 80, $1020-1028$

Folch, J., Lees, M., \& Sloane-Stanley, G. H. (1957). A simple method for the isolation and purification of total lipids from animal tissues. Journal of Biological Chemistry, 226, 497-509.

Gava, A. J. (1984). Principios de tecnologia de alimentos. São Paulo: Nobel.

Ip, C., \& Scimeca, J. A. (1997). Conjugated linoleic acid and linoleic acid are distinctive modulators of mammary carcinogenesis. Nutrition and Cancer, 27, 131-135.

Ip, C., Singh, M., Thompson, H. J., \& Scimeca, J. A. (1994). Conjugated linoleic acid suppresses mammary carcinogenesis and proliferative activity of the mammary gland in the rat. Cancer Research, 54, 1212-1215.

Janero, D. R. (1990). Malonaldehyde and thiobarbituric acidreactivity as diagnostic indices of lipid peroxidation and peroxidative tissue injury. Free Radical Biology Medicine, 9, 515-540.

Joo, S. T., Lee, J. I., Ha, Y. L., \& Park, G. B. (2002). Effects of dietary conjugated linoleic acid on fatty acid composition, lipid oxidation, color, water-holding capacity pork loin. Journal of Animal Science, 80, 108-112.

Jones, J. M. (1992). Factors influencing poultry meat quality. In D. E. Johnston, M. K. Knight, \& D. A. Ledward (Eds.), The chemistry of muscle-based foods (pp. 27-39). Cambridge: Royal Society of Chemistry.

Kelly, M.L., Bauman, D.E. (1996). Conjugated linoleic acid: a potent anticarcinogen found in milk fat. Proceedings of Cornell nutrition conference, Ithaca NY, pp. 68-74.

Lee, K. N., Kritchevsky, D., \& Pariza, M. W. (1994). Conjugated linoleic acid and atherosclerosis in rabbits. Atherosclerosis, 108, $19-25$.

Monahan, F. J., Asghar, A., Gray, J. I., Buckley, D. J., \& Morrissey, P. A. (1994). Effect of oxidized dietary lipid and vitamin $E$ on the colour stability of pork chops. Meat Science, 37, 205-215.

Parodi, P. W. (1977). Conjugated octadecadienoic acids of milk fat. Journal of Dairy Science, 60, 1550-1553.

Shantha, N. C., Crum, A. D., \& Decker, E. A. (1994). Evaluation of conjugated linoleic acid concentrations in cooked beef. Journal of Agriculture and Food Chemistry, 42, 1757-1760.

Shantha, N. C., Ram, L. N., O'Leary, J., Hicks, C. L., \& Decker, E. A. (1995). Conjugated linoleic acid concentrations in dairy products as affected by processing and storage. Journal of Food Science, 60, 695-697.

Sirri, F., Minelli, G., Meluzzi, A., \& Franchini, A. (2003). Quality traits and oxidative stability of n-3 PUFA enriched chicken meat. In , Proceedings of the 16th euyropean symposium on the quality of poultry meat, vol. 2 (pp. 258-264). INRA: Saint-Brieuc.

Tarladgis, B. G., Watts, B. M., Younathan, M. T., \& Dugan, L. R. (1960). A distillation method for the quantitative determination of malonaldehyde in rancid foods. Journal of American Oil Chemistry Society, 37, 44-48.

Universidade Federal de Viçosa-UFV. (1997). Manual de utilização do programa SAEG (Sistema para Análise Estatística e Genéticas). Viç osa: UFV.

West, D. B., Delany, J. P., Camet, P. M., Blohm, F., Truett, A. A., \& Scimeca, J. (1998). Effects of conjugated linoleic acid on body fat and energy metabolism in the mouse. American Journal of Physiology, 44, R667-R672.

Wong, M. W., Chew, B. P., Wong, T. S., Hosick, H. L., Boylston, T. D., \& Shultz, T. D. (1997). Effects of dietary conjugated linoleic acid on lymphocyte function and growth of mammary tumors in mice. Anticancer Research, 17, 987-993. 